\title{
EVALUATING PRIORITIES FOR FOREIGN DIRECT INVESTMENT IN BALTIC COUNTRIES
}

\author{
Assylkhan TURDYKHAN, Liucija BIRŠKYTË* \\ Department of Economics Engineering, Faculty of Business Management, \\ Vilnius Gediminas Technical University, Saulètekio al. 11, LT-10223, Vilnius, Lithuania \\ *E-mail: liucija.birskyte@vgtu.lt
}

\begin{abstract}
The purpose of this study is to assess the relative priority of three Baltic countries as a home country for foreign direct investment (FDI) inflow from the United States of America over the past four years (20142018). The study offers a structured model referring to a combination of the analytic hierarchy process (AHP) and the technique for order preference by similarity to ideal solution (TOPSIS). To provide valid answers to research question, the seven reliable determinants of FDI were selected from recent studies. The results for this time period show that productivity, market potential, market size, GDP growth and development have the highest priority im the decision-making process. However, this study has potential limitations. The evaluation of priorities of Baltic countries are based on a limited time period. The obtained findings help to evaluate trends of the activity of FDI and can assist policy makers and investors of multinational corporations with their challenges of strategic decision-making process.
\end{abstract}

Keywords: foreign direct investment, AHP, TOPSIS, selection criteria, Baltic countries, multinational companies.

\section{Introduction}

Almost all countries always try to attract foreign investments for positive impacts on economy of a country, as it makes a contribution to economic welfare in a very variety of ways: relaxing money constraints on investment, so that the capital stock might rise with FDI; paying higher wages created potentially through higher productivity; induced higher productivity in domestic companies through positive spillovers. The OECD defines foreign direct investment (FDI) as "an investment category that represent the purpose of establishing a long-lasting interest in a resident entity in one economy (direct investor) in a company (direct investment company) that is resident in an economy other than that of the direct investor" (OECD, 2018). From other point of view, multinational corporations with international investment activities always focus on minimanization of costs of the company. The management and financial decisions of companies are based on different determinants of FDI inflow-outflow, which may change over the time. According to recent studies (Beim \& Lévesque, 2006), research has focused on various factors of FDI attraction, including distance, gross domestic product (GDP), GDP growth rate, productivity, market size of host country, financial risks, corparate tax rates, country-pair specific impacts, such as language, border and colonial history, legal protection, and the quality of institutions. Furthermore, by obtained recent data from financial instutions and surveys from experts the seven reliable FDI determinants were identified, namely market size, development, GDP growth, market potential, productivity, distance, and taxation level. In our study Latvia, Lithuania and Estonia were selected as recipient countries for FDI inflow from the United States (U.S.), which is the third largest investor in Baltics after Sweden and Finland. The quantity of inward foreign direct investment per capita within the Baltic countries is significantly higher, compared to new EU members from Central and Eastern Europe (CEE). This is primarily the results of economic transformation, privatisation and a liberal, FDI-friendly environment. Most of the money and also the telecommunication sectors in addition as an oversized a part of the producing sector square measure foreign owned. Moreover, FDI could be an issue integrating these countries with their western neighbours than with alternative|ones For several multinational firms Estonia could be a bridgehead for investments within the other 2 countries. Notwithstanding the relatively high importance of FDI, there is very little academic research on the contributions of FDI the economic growth in Baltic countries, its evolution and determinants. As one prominent analyst of the region Pekka Sutela notes: "Perhaps due to the small size of the Baltic economies and also reflecting the weakness of domestic economic research, little analytical literature is available on these countries". In the United States lots of research waas devoted to the increase of FDI outflow 
towards the developed countries of OECD. However, no research has been reported on which FDI criteria are significant for Estonia, Lithuania and Latvia to attract investments from the United States. This article reports the findings of the study to establish the latest reliable FDI determinants as a main decision-making criteria and investigating the investment destination priorities in the last 4 years by developing a model based on a combination of AHP and TOPSIS techniques. AHP was implemented to obtain FDI determinant weights in the decision process, and the TOPSIS was employed to prioritize the alternatives. Investigating the FDI host countries' rankings in different time spans not only reinforces the validity of the designed model, but also results in a more comprehensive model. Using subjective methods helped obtaining more realistic results and increased the flexibility of the model. However, inputs based on various experts' judgments resulted in different weight distributions among the decision criteria and consequently changed the output of the entire model. Using a methodology that generates optimum output in prioritizing of countries to invest in will create greater added value for multinational enterprise companies and assist policymakers and investors in their strategic decision- making. Furthermore, the output of the decision about FDI priority is used as an input in many other decision-making processes, such as policymaking, the establishment of foreign relations with other countries, and the terms of different trade agreements. The remainder of this paper is organized as follows. The next section presents a literature review. Section 2 provides a discussion of the methodology used in evaluating the determinants of FDI. Section 3 reports and discusses the empirical results obtained. Section 4 is a discussion and provides final conclusions.

\section{Literature review}

Decision making is a method of choosing the best option among different alternatives. Wagner (1975) mentioned that "Unquestionably most, if not all, decision making is part of an unending history of action. Earlier choices have affected the present, current decisions will imfluence the future, and so on". As decision-making issues become difficult obtaining the best solution becomes more complicated. Finding the best option from different alternatives is naturally one of the main areas of interest areas in economics or finance, as a science which deals with the problem of scarce resources. In economics and finance literature, decision making processes are used to investigate several topics including evaluation of economic development differences, objective and subjective ratings (Chou, 2010), allocation of asset and mutual funds (Wagner, 1975) portfolio selection (Moosa, 2002), and energy management (Levary \& Wan, 1999).

The analytic hierarchy process (AHP) is one of the methods used to research a decision-making process in FDI area. AHP was developed by Saaty $(1977,1987)$, it is based on pairwise comparison. Hence, the importance of each criteria is compared one by one relative to the others. This process will be carried out by expert individual judgments and are scored using a specific ratio scale. This method solves and analyses problems similar to those addressed by the human brains. Levary and Wan (1999) developed AHP to rank the FDI entry mode possibilities of individual firms. In this approach, AHP is used to overcome the uncertainty of FDI including future expectations of foreign direct investment and pairwise comparisons of a decision-maker's judgment, which are entailed in AHP. In their explanatory example on the U.S. multinational FDI in China, they defined four alternatives including: whole ownership, majority- and minority-owned joint ventures and no entry as an entry mode, and subsequently ranking them according to their decision criteria (uncertainties) and five different scenarios. Grčić and Babić (2003) constructed AHP evaluation to rank particular transition countries (fifteen countries in Europe and the Baltic states) for FDI. In this study, several variables were employed as determinants of FDI. The results have revealed that the Central Eastern European and Baltic States (except Lithuania) at the top of the scale, and the Southeastern European countries are at the bottom of the scale. Gokmenoglu and Alaghemand (2015) used AHP, TOPSIS and MP - MADM methods to evaluate priorities for FDI inflow to the developed countries from the United States.

Hwang and Yoon (1981) constructed an approach, called the technique for order preference by similarity to ideal solution (TOPSIS). The approach in this methodology is quite unique but easy to comprehend. The best alternative from this method is selected based on the assumption; it should have the shortest Euclidean distance from the ideal solution and the farthest distance from the negative-ideal solution. The best alternative is obtained by the highest relative closeness measure. Lim and Tsai (2009) provided a model for ranking 15 regions and subsequently chose a location for FDI in Chinese recently developed hospitals. Karimi et al. (2009) examimed the location decision for FDI by applying TOPSIS methodology in ASEAN countries from 2000 to 2005. In order to provide the ranking, they defined ten indicators as FDI determimants imflows and subsequently concluded that among the considered countries, Singapore was most attractive country for investment. Other authors identified and prioritized various FDI methods for transfer of technology in the ship building industry using the Fuzzy TOPSIS method. They have shown that of various foreign investment methods, the joint venture and the subsidiary company have the highest and lowest priorities, respectively. 


\section{Data and methodology}

\subsection{Data description}

Data used in this study are annual figures for the period of 2014-2018. This model has been constructed to evaluate the U.S. FDI outflow priority in three FDI partnerships in Baltic region, namely Estonia, Latvia, Lithuania.

This study employs seven robust FDI criteria based on the study of Eicher et al. (2012) which constructed the determinants by considering two important constraints in an FDI database, i.e. uncertainty and selection bias. Table 1 references the data source for each determimant. Table 2 illustrates the bilateral and host country's FDI determinants that have been employed in this study, and also reveals the characteristic and effect of each determinant on FDI flows.

Table 1. Data source

\begin{tabular}{|c|c|}
\hline Criteria & Data source \\
\hline Distance & CEPII \\
\hline Market size & OECD \\
\hline Development & OECD \\
\hline GDP growth & OECD \\
\hline Market potential & CEPII \\
\hline Productivity & The World Bank \\
\hline Tax & KPMG \\
\hline
\end{tabular}

Table 2. FDI criteria

\begin{tabular}{|l|l|l|c|}
\hline \multicolumn{1}{|c|}{ Category } & \multicolumn{1}{|c|}{ Criteria } & \multicolumn{1}{|c|}{ Description } & $\begin{array}{c}\text { Effect on } \\
\text { FDI flow }\end{array}$ \\
\hline \multirow{2}{*}{ Gravity } & Distance & Natural log of bilateral distance & $(-)$ \\
\cline { 2 - 5 } & Market size & Host country natural log of real GDP(total) & $(+)$ \\
\hline $\begin{array}{l}\text { Factor } \\
\text { endowment }\end{array}$ & Development & Host country natural log of real GDP per capita & $(+)$ \\
\hline \multirow{2}{*}{\begin{tabular}{l} 
Productivity \\
\cline { 2 - 5 }
\end{tabular}} & GDP Growth & Host country GDP growth rate & $(+)$ \\
\cline { 2 - 5 } & Productivity & Sum of host country's distance-weighted GDP to all other countries & $(-)$ \\
\hline $\begin{array}{l}\text { Monetary } \\
\text { policy }\end{array}$ & Tax & Host country corporate effective taxrate & $(+)$ \\
\hline
\end{tabular}

\subsection{Methodology}

In this study, three types of analyses are employed. First, the AHP method is used to evaluate the FDI determinant weights in last four years. Second, a vector normalization approach is used to normalize all data relating to each set of FDI determinants for each country. Lastly, the TOPSIS method is applied to prioritize alternative countries based on defined FDI determinants. The AHP method was employed to determine the FDI criteria weight. The weights were calculated for the period based on expert judgments. A shown in Figure 1, hierarchical model is composed with a goal at the top level, the attributes at the second level and the alternatives at the third level.

There are two main steps of AHP process, as following:

Step 1: Construction of a pairwise comparison matrix to determine the relative importance of different criteria with respect to the goal based on Saaty's rating scale. The general pairwise comparison matrix can be constructed as shown in Table 3 (all arrays of the matrix are arranged by considering $a_{i j}=\frac{1}{a i j}$.

Step 2: Normalization of pairwise comparison matrix:

$$
n_{i j}=\frac{a i j}{\sum_{i=1}^{n} a i j}, \quad \text { where } i, j=1,2, \ldots, n .
$$




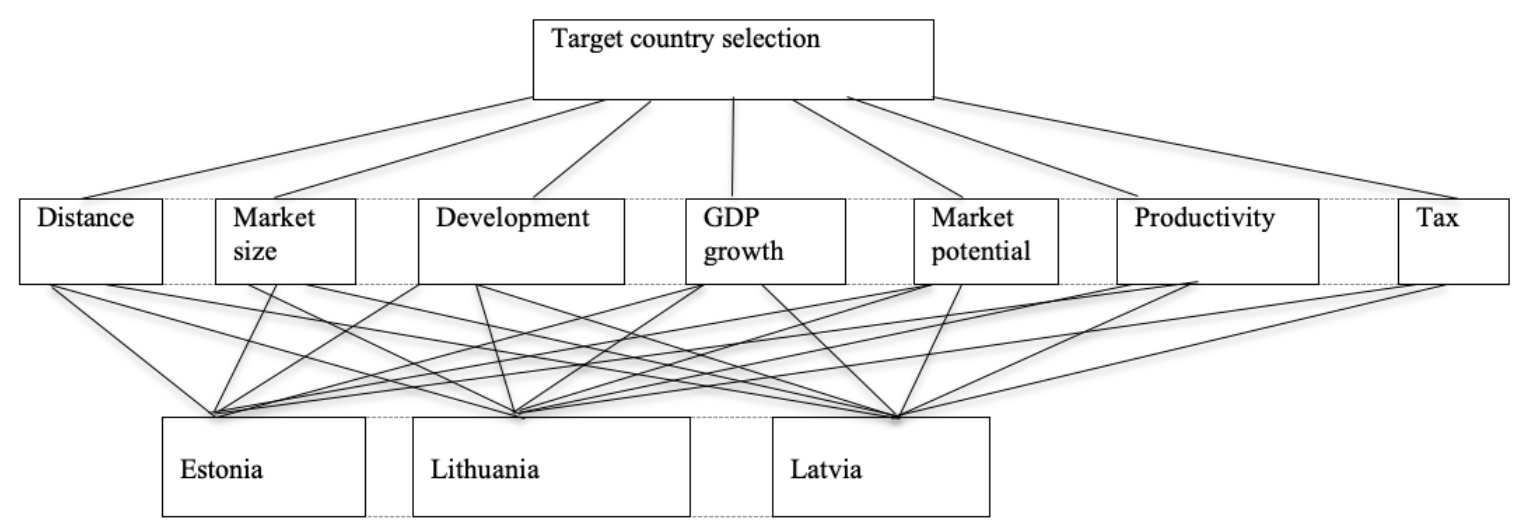

Figure 1. AHP model

Table 3. General pairwise comparison matrix

\begin{tabular}{|c|c|c|c|c|}
\hline Criteria & $\mathrm{C}_{1}$ & $\mathrm{C}_{2} \ldots$ & $\mathrm{C}_{\mathrm{j} \ldots}$ & $\mathrm{C}_{\mathrm{n} \ldots}$ \\
\hline $\mathrm{C}_{1}$ & 1 & $\mathrm{a}_{12 \ldots} \ldots$ & $\mathrm{a}_{1 \mathrm{j} \ldots} \ldots$ & $\mathrm{a}_{1 \mathrm{n}}$ \\
\hline $\mathrm{C}_{2 \ldots}$ & $1 / \mathrm{a}_{12 \ldots}$ & 1 & $\mathrm{a}_{2 \mathrm{j}}$ & $\mathrm{a}_{2 \mathrm{n}}$ \\
\hline $\mathrm{C}_{\mathrm{j} \ldots}$ & $1 / \mathrm{a}_{1 j} \ldots$ & $1 / \mathrm{a}_{2 \mathrm{j}}$ & 1 & $\mathrm{a}_{\mathrm{im} \ldots}$ \\
\hline $\mathrm{C}_{\mathrm{n} \ldots}$ & $1 / \mathrm{a}_{1 \mathrm{n}}$ & $1 / \mathrm{a}_{2 \mathrm{n}}$ & $1 / \mathrm{a}_{\mathrm{i} m \ldots} \ldots$ & 1 \\
\hline
\end{tabular}

At the end of this step, criteria weights are calculated and following steps are followed to test the consistency of judgments. The calculation the consistency is employed to check reliability of expert judgements for the corresponding matrix.

\subsection{Methodological fundamentals of consistency in AHP}

The evaluation requires a certain level of matrix consistency, i.e. that the elements are linear independent. That can be assessed employing consistency index CI as follows: firstly weighted sum vector is calculated to determine the $\lambda$ max (the highest eigenvalue of the matrix) has to be calculated like so (Saaty, 1977):

$$
W S V=\text { pairwise comparison matrix } \times \text { matrix of } w_{j}(\operatorname{step} 2) .
$$

Calculation of the maximum Eigen value of the pairwise comparison $\left(\lambda_{\max }\right)$ :

$$
\lambda_{\max }=\frac{\sum(W S V / W j(\text { eacharrayonebyone })}{n} .
$$

Calculation of the consistency imdex $(\mathrm{CI})$ and consistency ratio (CR):

$$
C I=\frac{\lambda \max -n}{n-1}, \quad C R=\frac{C I}{R I},
$$

where $n$ represents the independent rows of matrix, $R I$ is represented by average CI values gathered from a random simulation of Saaty pair-wise comparison matrices CIs. The suggested value of the CR should be no higher than 0.1 (Saaty, 1987). If the matrix is perfectly consistent, then $C I=0$.

\subsection{TOPSIS}

Among various MCDM methods, TOPSIS, proposed by Hwang and Yoon (1981) is used widely and based on the copcept of the comprimised solution. Generally, in TOPSIS method, the alternative is chosen that should simultaneously have the shortest distance from the positive ideal solution (PIS) and the longest distance from the negative ideal solution (NIS). The PIS is a solution that maximizes all the benefit criteria and mimimizes all the cost criteria, where as the NIS is a solution that maximizes all the cost criteria and mimimizes all the benefit criteria. However, neither the PIS nor the NIS exists; otherwise making decisions would be very easy.Therefore, how to balance the separations of alternative from the PIS and the NIS plays an influential role im realistic decisionmaking The application of TOPSIS requires decision matrix with set of alternatives over set of criteria and the 
specification of relative weights towards these criteria. There are six major steps to achieve the optimum ranking of alternatives:

Step 1: Normalization of the decision matrix. The normalized value is calculated as:

$$
\mathrm{y}_{\mathrm{ij}}=\frac{x i j}{\sqrt{\sum_{i=1}^{n} x i j^{2}}}, \quad i=1,2, \ldots . n . v_{i j} .
$$

Step 2: Calculation of a weighed normalized decision matrix: Multiplication of a normalized decision matrix (R) with respect to a diagonal matrix of criteria weights $(W n \times n)$

$$
V=R \times W n \times n .
$$

Step 3: To determime the ideal positive $\left(\mathrm{V}_{\mathrm{j}}^{+}\right)$and negative $\left(\mathrm{V}_{\mathrm{j}^{-}}\right)$solutions:

$\left(\mathrm{V}_{\mathrm{j}}^{+}\right):\left[\mathrm{v}_{1}{ }^{+}, \ldots, \mathrm{v}_{\mathrm{j}}{ }^{+}, \mathrm{v}_{\mathrm{n}}^{+}\right]$. The best value for positive and negative criteria will be the maximum and mimimum amout, respectively.

$\left(\mathrm{V}_{\mathrm{j}}^{-}\right):\left[\mathrm{v}_{1^{-}}, \ldots, \mathrm{v}_{\mathrm{j}}^{-}, \mathrm{v}_{\mathrm{n}}^{-}\right]$. The worst value for positive and negative criteria will be the mimimum and maximum amount, respectively.

Step 4: To find separation measures using Euclidean distance from the positive $\left(\mathrm{V}_{\mathrm{j}}^{+}\right)$and negative $\left(\mathrm{V}_{\mathrm{j}^{-}}\right)$ideal alternatives:

$$
D_{j}^{+}=\sqrt{\sum_{j=1}^{n}\left(v \imath j-v_{j}^{+}\right)^{2}}, \quad i=1,2, \ldots, m,
$$

where $v_{\mathrm{j}}{ }^{+}$is the best value for each attribute irrespective of the alternative.

$$
D_{j}^{-}=\sqrt{\sum_{j=1}^{n}\left(v \imath j-v_{\mathrm{j}}^{-}\right)^{2}}, \quad i=1,2, \ldots, m,
$$

where $v_{j}^{-}$is the worst value for each attribute.

Step 5: To calculate the ranking index CL, relative closeness of alternarive with respect to PIS:

$$
C L_{i}=\frac{D i^{-}}{D i^{-}+D i^{+}} .
$$

Step 6: Rank alternatives: arranging ranking indexes in descendimg order to obtain the best alternative.

\section{Empirical results}

\subsection{Criteria weighting}

The AHP method was employed to calculate the weights for each criterion in this study. The weighting process was carried out for each period separately as indicated in the previous sections. To complete the pairwise comparison matrix, we considered the expert judgments of three American imvestment experts in Baltic countries. Figure 2 illustrates the aggregated FDI criteria weights with respect to the AHP method.

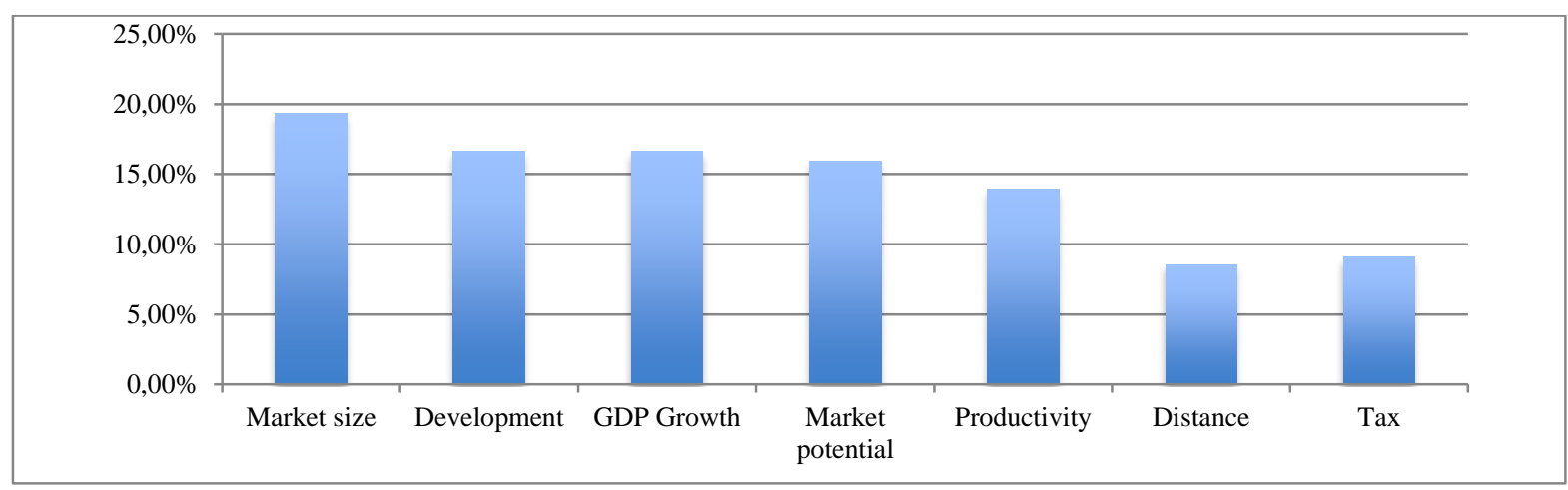

Figure 2. Average FDI criteria weights rankings

To reach the desired degree of consistency in the expert judgments, the consistency indexes were calculated for each of the three matrixes using steps 2 to 4 (see Table 4). 
Table 4. Consistency indexes

\begin{tabular}{|c|c|c|c|}
\hline & $1^{\text {st }}$ expert & $2^{\text {nd }}$ expert & $3^{\mathrm{d}}$ expert \\
\hline$\lambda \max$ & 7.935 & 7.963 & 7.74 \\
\hline Consistency index & 0.155 & 0.161 & 0.124 \\
\hline
\end{tabular}

Note: The CI calculations for the matrices demonstrate that the required degree of consistency was achieved. Accoding to Saaty when $n=7$, RI is 1.32. In all three matrices Consistency index is much more smaller than RI.

The CI calculations for the matrices demonstrate that the required degree of consistency was achieved.

\subsection{Normalization}

The next step after gathering data for all FDI determinants was normalization of the decision matrixes based on Eq. (5). As indicated in Table 5, all the decision matrix arrays are in the same dimension, so that the comparison among them becomes applicable.

Table 5. Quantification of the decision matrix

\begin{tabular}{|l|c|c|c|c|c|c|c|}
\hline Alternatives & $\begin{array}{c}\text { Market size } \\
\text { (log of GDP } \\
\text { total im US } \\
\text { dollars) }\end{array}$ & $\begin{array}{c}\text { Development } \\
\text { (log of GDP } \\
\text { per capita) }\end{array}$ & $\begin{array}{c}\text { GDP growth } \\
\text { (average of } \\
\text { annual growth } \\
\text { rate) }\end{array}$ & $\begin{array}{c}\text { Market } \\
\text { potential }\end{array}$ & $\begin{array}{c}\text { Productivity } \\
\text { (GDP per } \\
\text { person } \\
\text { employed) }\end{array}$ & Distance & $\begin{array}{c}\text { Tax } \\
\text { (corporate } \\
\text { tax rate) }\end{array}$ \\
\hline Latvia & 4.776 & 4.482 & 3.0716 & 34 & 59.081 & 95.59013 & 15 \\
\hline Lithuania & 4.995 & 4.548 & 3.198 & 36 & 64.221 & 96.11483 & 15 \\
\hline Estonia & 4.677 & 4.557 & 3.604 & 37 & 64.494 & 79.98945 & 20 \\
\hline
\end{tabular}

\subsection{TOPSIS results and analysis}

After calculating the normalized decision matrices, the next step was the construction of a weighted normalized decision matrix based on equation (6). This step was employed for each year employing the criteria weight matrix. In order to aggregate yearly decision matrixes in our defined economic periods, a weighted vector was selected. The next step in the TOPSIS was to determine the positive and negative ideal solutions. In this regard, for criteria that identify a positive condition, the positive ideal solution is the maximum value, and the negative ideal solution is the mimimum value. On the other hand, for criteria that identify a negative condition, the positive and negative ideal solutions are the mimimum and maximum values, respectively. For instance, in our study, distance was characterized as a negative criteria given that as bilateral distance increases, FDI flow decreases. As indicated in Table 6, the distance of each alternative from the positive and negative ideal solutions was calculated using Eqs. (7) and (8). The last step was to rank (in descending order) the relative closeness indexes, the highest values in the CL index, and the better alternatives for investment (see Table 7).

Table 6. Normalization of the decision matrix

\begin{tabular}{|c|c|c|c|c|c|c|c|}
\hline $\begin{array}{c}\text { Vector } \\
\text { normali } \\
\text { zation }\end{array}$ & $19.30 \%$ & $16.61 \%$ & $16.62 \%$ & $15.92 \%$ & $13.92 \%$ & $8.54 \%$ & $9.08 \%$ \\
\hline $\begin{array}{c}\text { Alterna- } \\
\text { tives }\end{array}$ & $\begin{array}{c}\text { Market size (log } \\
\text { of GDP total in } \\
\text { US dollars) }\end{array}$ & $\begin{array}{c}\text { Development } \\
\text { (log of GDP } \\
\text { per capita) }\end{array}$ & $\begin{array}{c}\text { GDP growth } \\
\text { (average of annual } \\
\text { growth rate) }\end{array}$ & $\begin{array}{c}\text { Market } \\
\text { potential }\end{array}$ & $\begin{array}{c}\text { Productivity } \\
\text { (GDP per person } \\
\text { employed) }\end{array}$ & $\begin{array}{c}\text { Distance } \\
\text { (corporate } \\
\text { tax rate) }\end{array}$ \\
\hline Latvia & 0.110 & 0.095 & 0.089 & 0.088 & 0.076 & 0.052 & 0.047 \\
\hline Lithuania & 0.116 & 0.096 & 0.093 & 0.093 & 0.082 & 0.052 & 0.047 \\
\hline Estonia & 0.108 & 0.097 & 0.105 & 0.095 & 0.083 & 0.043 & 0.062 \\
\hline
\end{tabular}

Table 7. Ranking of alternatives

\begin{tabular}{|l|c|c|c|c|}
\hline Alternatives & $\begin{array}{c}\text { Euclidean distance } \\
\text { from the best }\end{array}$ & $\begin{array}{c}\text { Euclidean distance } \\
\text { from the worst }\end{array}$ & $\begin{array}{c}\text { Performance } \\
\text { score }\end{array}$ & Rank \\
\hline Latvia & 0.0196947 & 0.017538029 & 0.471038467 & 3 \\
\hline Lithuania & 0.0155799 & 0.019032859 & 0.549879422 & 1 \\
\hline Estonia & 0.0188770 & 0.019160796 & 0.503730664 & 2 \\
\hline
\end{tabular}




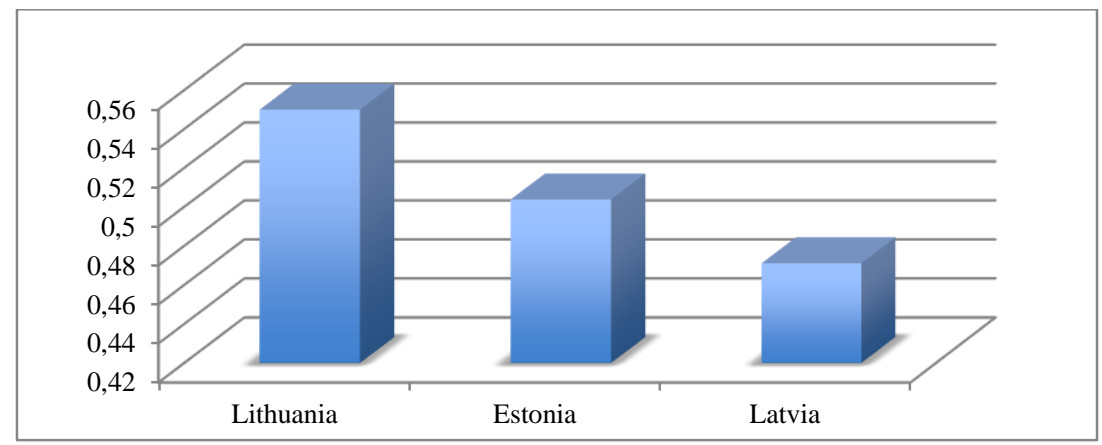

Figure 3. Alternative ranking of Baltic countries for 2014 and 2018 years

As shown in Figure 3, according to the designed output model, the U.S.'s first priority in increasing FDI outflow in the periods from 2014 to 2018 is Lithuania. However, values for Lithuania is not much more different from Estonia. In 2015, Lithuania became the 19th member of Euro Area. Lithuania's service sector constitutes the largest share of GDP with information and communication technologies being the fastest growing. Also, in recent years Lithuania has shifted towards a knowledge-based economy: several companies produce sophisticated biotech products like pharmaceutical substances, components for molecular diagnostics and laser equipment (OECD, 2018). On the expenditure side, household consumption is the main component of GDP and accounts for 63 percent of its total use, followed by gross fixed capital formation (19 percent) and government expenditure (17 percent) (OECD, 2018). Exports of goods and services account for 81 percent while imports account for 79 percent, adding 2 percent of total GDP (OECD, 2018).

Additionally, Lithuania's forceful relationship with developing countries in Asia makes the country a good business opportunity for foreign investors. Lithuania is considered a transit country, connectimg Europe with the Asian part of world.Due to time limitations, this research covers data only from 2014 and 2018, Estonia became at the second place. According to economical growth of Estonia, it was in the leading place starting from the late 2016. According to Statistics Estonia, in 2018, the gross domestic product (GDP) of Estonia increased 3.9\% compared to 2017. For the third consecutive year the economic growth im Estonia was faster than 3\%. In the 4th quarter of 2018, the Estonian economy increased by $4.2 \%$ compared to the 4th quarter of 2017 (OECD, 2018).

\section{Discussion}

As with many other studies that have investigated the determinants of FDI, this empirical work also takes into account the possibility that both the decision- making criteria and their importance to decision makers may change over time. Missing data jeopardize the validity of FDI theories. In order to avoid selection bias, seven robust FDI determinants were employed in our model. This study aimed to contribute to the literature by considering the latest robust FDI determinants as decision-making criteria and by investigating investment destination priorities in three different years, and by developing a model based on a combination of AHP and TOPSIS techniques. This combination of methods has meant that our results are more robust and to the best of our knowledge have not as yet been employed in investigating determinants of FDI. In addition, it should be pointed out that the process of pairwise comparison relating to criteria weight determination was carried out after 2018 even though expert judgments were required in order to consider the environmental factors that existed in each period. Specifically, the judgments may differ since they were made during each year.. Meanwhile, considering the subjective attribution of the AHP method, during this study only three investment experts' opinions were considered, partly due to our limited access to investment experts. Increasing the number of experts could reinforce the validity of the criteria weights in this methodology. Therefore, based on the above considerations, the following findings were obtained from our analysis. This model can be used for various sets of countries in different spans of time as well. In addition, it could be considered an important decision-making tool for obtaining optimum results. Policymakers and other decision makers can obtain the best priority in increasing FDI outflows to destination countries in different economic situations. Meanwhile, this model can assist policymakers in dealing with different aspects of FDI. This model can also help to improve the investment climate and relations between countries. In addition, investment barriers can be identified and analyzed when using this method. Further research might use different decisionmaking approaches such as SAW and ELECTRE, or employ aggregated methodologies such as the Borda and Copeland methods for prioritizing the alternatives. Moreover, window data envelopment analysis (DEA) can be implemented to analyze the priority of alternatives and the efficiency of the decision-making unit during the different periods. The designed framework can be also used in different fields, such as project management, portfolio management, tourism management, and so on. 


\section{Conclusions}

This study attempted to design a model to evaluate the attractiveness of the Baltic countries for FDI. The findings show that productivity, market potential, market size, GDP growth, and development were the most important determinants of FDI. This study shows that the size of a country's economy and its growth potential are pivotal factors for FDI inflow. Such a conclusion that should provide guidance for policymakers in countries that are competing for FDI inflow. Any change in criteria weight ranking also affects the position of the countries in the alternative ranking table. The importance of development, GDP growth, market size, and market potential during the post-crisis period affected significantly the priority of the target countries' FDI. The aggregated data for this period has revealed that Lithuania and Estonia each played a vital role as a host country for the U.S. investments. When it comes to market size, distance and corporate tax, Lithuania in comparison to the other countries is in the leading position. Other factors, such as strong GDP growth, development, and market potential account for the US being the largest foreign investor in Estonia.

\section{References}

Beim, G., \& Lévesque, M. (2006). Country selection for new business venturimg: a multiple criteria decision analysis. Long Range Planning, 39(3), 265-293. https://doi.org/10.1016/j.lrp.2006.06.001

Chou, C. C. (2010). An integrated quantitative and qualitative FMCDM model for location choices. Soft Computing, 14(7), 757-771. https://doi.org/10.1007/s00500-009-0463-8

Eicher, T. S., Helfman, L., \& Lenkoski, A. (2012). Robust FDI determimants: Bayesian model averaging in the presence of selection bias. Journal of Macroeconomics, 34(3), 637-651. https://doi.org/10.1016/j.jmacro.2012.01.010

Gokmenoglu, K. K., \& Alaghemand, S. (2015). A multi-criteria decision-makimg model for evaluatimg priorities for foreign direct imvestment. Croatian Operational Research Review, 6(2), 489-510. https://doi.org/10.17535/crorr.2015.0037

Grčić, B., \& Babić, Z. (2003, May 22-24). The determimants of FDI: evaluation of transition countries attractiveness for foreign investors. In Proceedings of the $5^{\text {th }}$ International Conference "Enterprise in Transition" (pp. 1166-1180), SplitTučepi, Hrvatska. https://www.bib.irb.hr/139692

Hwang, C.-L., \& Yoon, K. (1981). Multiple attribute decision making - methods and applications a state-of-the-art survey. In Multiple attribute decision making. Springer-Verlag Berlin Heidelberg.

Karimi, M., Yusop, Z., \& Hook, L. S. (2009). Location decision for foreign direct investment in ASEAN countries (A TOPSIS Approach) (MPRA paper, No. 15000). https://mpra.ub.uni-muenchen.de/id/eprint/15000

Levary, R. R., \& Wan, K. (1999). An analytic hierarchy process based simulation model for entry mode decision regarding foreign direct investment. Omega, 27(6), 661-677. https://doi.org/10.1016/S0305-0483(99)00032-8

Lim, C.-T., \& Tsai, M.-C. (2009). Development of an expert selection system to choose ideal cities for medical service ventures. Expert Systems with Applications, 36(2), 2266-2274. https://doi.org/10.1016/j.eswa.2007.12.056

Moosa, I. A. (2002). Foreign direct imvestment: theory, evidence, and practice. Palgrave.

Navaretti, B. G., \& Venables, A. (2006). Multinational firms in the world economy. https://econpapers.repec.org/bookchap/puppbooks/7832.htm

OECD. (2018). The OECD benchmark definition. https://www.oecd.org/

Saaty, T. L. (1977). A scaling method for priorities in hierarchical structures. Journal of Mathematical Psychology, 15(3), 234-281. https://doi.org/10.1016/0022-2496(77)90033-5

Saaty, T. L. (1987). The analytic hierarchy process-what it is and how it is used. Mathematical Modelling, 9(3-5), 161-176. https://doi.org/10.1016/0270-0255(87)90473-8

Wagner, H. M. (1975). Principles of operation research with application to managerial decisions. Prentice-Hall, Englewood Cliffs.

\section{BALTIJOS ŠALIŲ PATRAUKLUMO TIESIOGINĖMS UŽSIENIO INVESTICIJOMS VERTINIMAS}

\section{Assylkhan TURDYKHAN, Liucija BIRŠKYTĖ}

Santrauka. Šiame straipsnyje bandoma įvertinti trijų Baltijos šalių santykinị patrauklumą tiesioginėms užsienio investicijoms (TUI) iš Jungtinių Amerikos Valstijų per pastaruosius keturis metus (2014-2018). Tyrimo eigoje buvo sukurtas struktūrizuotas modelis apjungiantis dvi metodikas: analitinị hierarchinị procesą (AHP) ir techniką leidžiančią nustatyti preferencijų eiliškumą lyginant jas su idealiu sprendimu (TOPSIS). Siekiant gauti patikimą atsakymą ị išsikeltą tyrimo klausimą, remiantis naujausia literatūra buvo atrinktos septynios TUI determinantès. Rezultatai rodo, kad per tyrimo laikotarpi priimant investavimo sprendimus svarbiausi faktoriai buvo produktyvumas, rinkos galimybès, rinkos dydis, BVP augimas ir plètra. Tyrimo validumas nukenčia dèl per trumpo nagrinëjamo laikotarpio. Nepaisant šio ribotumo gauti rezultatai gali padèti ịvertinti TUI judejjimo tendencijas ir yra naudingi ekonominès politikos formuotojams ir tarptautinèms bendrovèms priimant strateginius sprendimus.

Reikšminiai žodžiai: tiesioginės užsienio investicijos, AHP, TOPSIS, atrankos kriterijai, Baltijos šalys, tarptautinès bendrovės. 